Primljen / Received: 20.12.2017 Ispravljen / Corrected: 29.6.2018.

Prihvaćen / Accepted: 17.7.2018.

Dostupno online / Available online: 10.2.2019.

\title{
Comparison and assessment of material models for simulation of infilled RC frames under lateral loads
}

Authors:

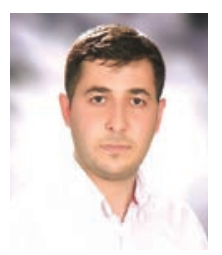

Mehmet Ömer Timurağaoğlu, MSc. CE

Uludağ University, Turkey

Department of Civil Engineering

Faculty of Engineering

omertao@uludag.edu.tr

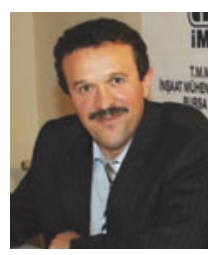

Prof. Adem Doğangün, PhD. CE

Uludağ University, Turkey

Department of Civil Engineering

Faculty of Engineering

adogangun@uludag.du.tr



Prof. Ramazan Livaoğlu, PhD. CE

Uludağ University, Turkey

Department of Civil Engineering

Faculty of Engineering

rliva@uludag.edu.tr
Mehmet Ömer Timurağaoğlu, Adem Doğangün, Ramazan Livaoğlu

Subject review

\section{Comparison and assessment of material models for simulation of infilled RC} frames under lateral loads

In the present study, the behaviour of infilled RC frames under earthquake loading is investigated numerically, and the influence of three different concrete material models on the in-plane behaviour of infilled RC frames is evaluated using the finite element analysis (FEA). For this reason, the efficiency of infilled walls is examined on full scale models. Finite element analysis results show that mathematical model of concrete may change behaviour of infilled RC frames. The post-peak behaviour is especially influenced.

\section{Key words:}

material model, Infill wall, reinforced concrete, finite element method

Pregledni rad

Mehmet Ömer Timurağaoğlu, Adem Doğangün, Ramazan Livaoğlu

Usporedba i ocjena modela za simulaciju ponašanja $A B$ okvira s ispunom pod bočnim opterećenjem

U radu se numerički istražuje seizmičko ponašanje AB okvira s ispunom, te se proračunom konačnih elemenata (FEA) ocjenjuje utjecaj triju različitih betonskih modela na ravninsko ponašanje AB okvira s ispunom. U tu se svrhu učinkovitost ispune ocjenjuje na modelima u prirodnoj veličini. Rezultati proračuna konačnih elemenata pokazuju da matematički model betona može promijeniti ponašanje AB okvira s ispunom. Utjecaj je naročito značajan za ponašanje nakon vršnog opterećenja.

Ključne riječi:

materijalni model, ispunski zid, armirani beton, metoda konačnih elemenata

Übersichtsarbeit

Mehmet Ömer Timurağaoğlu, Adem Doğangün, Ramazan Livaoğlu

Vergleich und Bewertung des Modells für die Simulation des Verhaltens von Stahlbetonrahmen mit Füllung bei seitlicher Belastung

In der Abhandlung wird das seismische Verhalten von Stahlbetonrahmen mit Füllung nummerisch untersucht, und durch die Finite-Elemente-Berechnung (FEA) wird der Einfluss dreier unterschiedlicher Betonmodelle auf das Gleichgewichtsverhalten der Stahlbetonrahmen mit Füllung bewertet. Zu diesem Zweck bewertet man die Wirksamkeit der Füllung an Modellen in natürlicher Größe. Die Ergebnisse der FiniteElemente-Berechnung zeigen, dass das mathematische Betonmodell das Verhalten der Stahlbetonrahmen mit Füllung verändern kann. Der Einfluss ist besonders für das Verhalten nach der Spitzenbelastung wichtig.

Schlüsselwörter:

Materialmodell, Massivwand, Stahlbeton, Finite-Elemente-Methode 


\section{Introduction}

Infill walls in RC frame structures are widely used for various reasons in Turkey and in many other countries worldwide. Infill walls, also called masonry infill walls, are comprised of units with mortar and can be constructed using different units such as brick, gas concrete, or solid brick. Masonry infill walls can be with openings and without openings, depending on requirements. The wall behaviour is rather difficult to understand since the units and mortar exhibit different size, dimensions, and mechanical properties, and because of the interactions between the wall and the frame.

Although it is known that infill walls improve the stiffness and strength of the frame, the contribution of infill walls is usually neglected in structural analysis. The most important disadvantage of infilled RC frames is the fast degradation of stiffness, as well as rapid reduction of strength and dissipation of energy under seismic loading. On the other hand, despite its contribution to the structures, on-site damage assessments after earthquakes reveal that infill walls have some detrimental effects on the behaviour of structures. These disadvantages have been experienced many times and seen in many examples after earthquakes, as a result of torsion, soft storey, weak storey, and short column effects. A detailed explanation of these effects is available in literature [1]. Additionally, a very stiff infill wall may behave like an unreinforced shear wall and cause damage to columns due to formation of a diagonal equivalent strut in infill during earthquakes, as shown in Figure1.
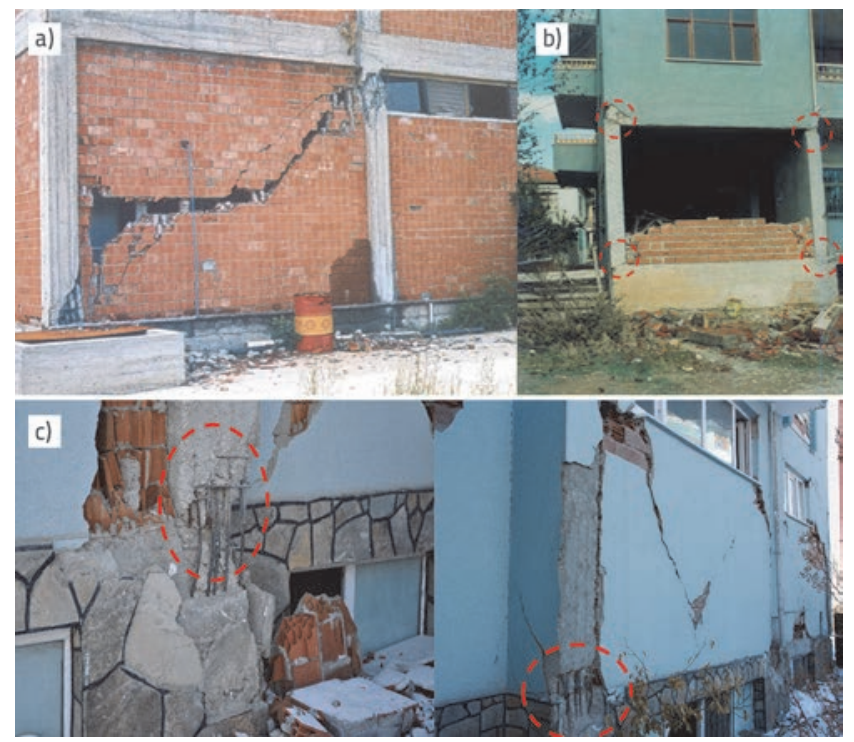

Figure 1. Damaged infilled frame: a) 1998 Adana-Ceyhan earthquake [3]; b) 1995 Dinar earthquake [4], c) 2011 Van earthquake

Finite element modelling of structures has brought significant advances in the sphere of simulation of complicated engineering problems. It is especially practical for infilled frame structures whose behaviour depends on several parameters. The modelling of infilled frames can basically be classified into two groups: macromodelling and micromodelling. A macromodel tries to encompass the overall (global) behaviour of a structural element without modelling all possible modes of local failure. Micromodels, on the other hand, model behaviour of a structural element with great attention to details, trying to encompass all possible modes of failure [2].

Many investigators have used the finite element method (FEM) to understand the behaviour of infilled RC frame systems under seismic loading. In [5], the authors have used a smeared-crack model to represent the behaviour of concrete in the RC frames and masonry units. In [6], the authors have formulated a nonassociated interface model using available test data on masonry joints in order to model the interface between the frame and infill and mortar joints surrounding the blocks of masonry. In [7], the authors have used a cohesive interface model to simulate the behaviour of mortar joints between masonry units and the behaviour of frame-panel interface and a smeared crack finite element formulation, to model concrete in RC frames and masonry units. Reference [2], the authors proposed a realistic criterion to describe the frame-infill separation in order to simulate the complicated behaviour of infilled frames under lateral loads. Based on the results obtained from 189 computational models, the authors of [8] found that the number of floors (height of building) and the percentage of shear walls, are the primary parameters affecting the fundamental period of the structure. Additionally, the percentage of infill walls and the number of bays have almost the same influence on the fundamental period of structures. Discrete and smeared crack modelling approaches are combined in [9] to overcome the inadequacy of smeared crack elements in simulating the brittle shear behaviour of RC members and mixed-mode fracture of masonry mortar joints. The damage plasticity constitutive model for masonry, usually used for concrete and other quasibrittle materials is adopted in [10]. A discrete method of analysis with the damage-based cohesive crack modelling technique for numerical simulations of masonry infilled RC frame failure is proposed in [11]. A state-of-the-art mathematical micromodelling of infilled frames pointing out the advantages and disadvantages of each micro-modelling is presented in [12]. An alternative approach for simulation of seismic behaviour of infilled frame structures, which can be used from macro to micro scale structures, is proposed in [13]. The cyclic response of masonry infilled RC frames using experimental test results and a modified pivot model is investigated in [14]. Following a detailed and in-depth analytical investigation on the parameters that affect the fundamental period of RC structures, it has been established in [15] that the number of stories, the span length, the stiffness of the infill wall panels, the location of the soft stories, and the soil type, are crucial parameters that influence the fundamental period of RC buildings. A large literature review including modelling techniques developed in the last decades, going from refined nonlinear FE micromodel approaches to simplified equivalent single or multiple strut macro models is provided in [16]. The mechanical behaviour of infilled frames 
under in-plane lateral loading and an analytical law considering the effects of vertical loads on the characteristics of pin-jointed diagonal strut is discussed in [17]. An analytical expression, taking into account the effects of opening and vertical load, for the determination of the equivalent strut width considering extensive numerical finite element models, has recently been proposed in [18]. An alternative macro-element approach for seismic assessment of infilled frame structures is proposed in [19]. A multi-storey plane frame prototype is investigated and results are compared with a commonly used single-strut model. More recently, the influence of distributed and concentrated loading on infilled steel frame is studied in [20]. The results obtained show that the distributed loading results in a 18.5 and $29 \%$ increase in the strength and stiffness of Infilled frames. After conducting an experimental research on masonry-infilled $\mathrm{RC}$ frames with various lateral strengths, the lateral design strength ratio of RC frame to masonry infill, in-filled with hollow clay blocks, greater than 1.2 (including the partial safety factor of 1.3) is suggested in order to have controlled failure mechanisms and to reduce the negative impacts of masonry infills on RC frames [21]. In a parametric study, failure surface parameters and dilation angle were shown to have a significant effect on the ultimate strength, cracking stiffness, as well as on the preand post-ultimate behaviour of the infilled frames, while those for fracture energy were shown to have only a small degree of influence on the ultimate load and post-ultimate behaviour of the models [22]. Furthermore, a relationship between inter-storey drift demands of bare and infilled structural configurations has been proposed to control the damage of masonry infill [23]. Also, performance-based evaluation of in-plane cyclic tests on RC frames with strong masonry infill, especially the infill performance, the related damage distribution, the lateral stiffness, the strength and dissipation capacity with a possible definition of performance limit states, is studied in [24]. A stateof-the-art study on modelling of masonry infilled RC frames subjected to cyclic loads has lately been published [25]. The infill wall configuration relevant to short column effect of a RC frame has also been investigated [26].

In recent years, the effects of openings and vertical loads on the seismic behaviour of infilled frames have been investigated by several researchers. The effects of openings on the seismic performance of infilled RC frames are investigated experimentally in [27] and a compressive strut model for infilled RC frames with openings is proposed. Based on numerical analysis on masonry infilled RC frames with typical window and door openings, appropriate empirical formulas are proposed in [28]. The experimental results showed that window and door openings exert a significant influence on the lateral resistance, initial stiffness and energy dissipation capacity of systems. According to experimental and numerical analysis, the presence of larger openings in infill produces only a limited improvement in strength compared to bare frame [19] and a limited influence on the mode of failure [29] while the effect of vertical loads on the stiffness of the dimensionless strut width is significant for fully infilled panels and almost negligible for infill panels with large openings [18].

Additionally, the out of plane (OOP) response of infilled frames is also a crucial concern that causes loss of life during earthquakes. The majority of experimental data suggest that after initial cracking of the infill wall, the OOP strength depends on the compressive strength of the masonry, rather than on its tensile strength [13]. A literature review of OOP behaviour of infilled frame, starting from the early flexural based models and reaching up to the recent in-plane(IP)-OOP integrated macromodels, has recently been presented in [30].

The importance of infilled frame structures (IFS) has been emphasized by several researchers as indicated above. Many investigators have studied the IFS experimentally, while others have focused on numerical or analytical study of the IFS. However, to the knowledge of the authors, the influence of concrete mathematical models has not been sufficiently studied in the scope of numerical studies.

Taking into account the above considerations, the study is focused on the effects of material models of concrete, which are well known and widely preferred in the literature. In this context, it is worth mentioning that other complex concrete models shown in literature, i.e. nonlinear cementitious, sbeta, etc. [31] are beyond the scope of the study. Therefore, the aim of this study is to study the influence of the concrete mathematical models on the behaviour of infilled frame structures (IFS) by means of the finite element method (FEM). For this reason, a full scale, one bay and one storey RC frame, with and without infill wall, is modelled and analysed under lateral loads using FEM. The experimental campaigns for the model were conducted earlier in the literature. Additionally, the influence of the surface based cohesive behaviour, which is used to represent the interaction between the infill wall and the surrounding frame, is investigated in this paper.

\section{Brief summary of experimental program}

\subsection{Prototype structure and test specimens}

The experimental campaign of this study was conducted by the authors of this paper, and also by the author of [32], at the structural laboratory of the Karadeniz Technical University (KTU) in order to investigate performance of unreinforced and reinforced masonry infilled frames subjected to reversible lateral loads.

One bare frame and two infilled RC frame specimens were analysed in the scope of experimental tests: gas concrete infilled RC frames and hollow brick infilled RC frames. A onestorey one-bay RC frame was selected as a prototype structure. The height/length (h/l) ratio for infill walls was selected to be $1 / 1.25$. The reinforcement was designed in accordance with normal practice for existing buildings in Turkey. The test specimens were chosen to be $1 / 1$ scale reflecting the existing structures in Turkey. The design details for the frame specimens are shown in Figure 2. The columns and beam were selected 
to be $20 \times 25 \mathrm{~cm}$ and $25 \times 20 \mathrm{~cm}$, respectively. Dimensions of the wall were $250 \times 200 \times 20 \mathrm{~cm} .400 \times 60 \times 40 \mathrm{~cm}$ dimensions were selected for the rigid base of the frame. Six bars $14 \mathrm{~mm}$ in diameter were used as longitudinal reinforcement in columns. Three bars $12 \mathrm{~mm}$ in diameter were used as longitudinal reinforcement at the bottom of the beam and two bars $12 \mathrm{~mm}$ in diameter were used at the top for beam. Confinement details for columns and beam are shown in Figure 2. The rigid base is fixed to the ground with shear connectors. The test specimen shown in Figure 2 is subjected to lateral cyclic loads. The loads are applied to the system by increasing the amplitude in each cycle, as shown in Figure 3.

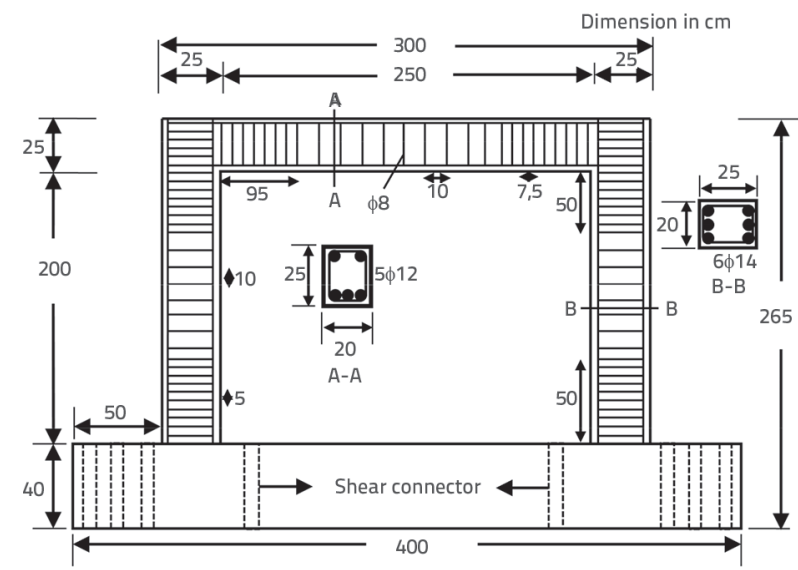

Figure 2. Dimensions and reinforcement details of test specimens

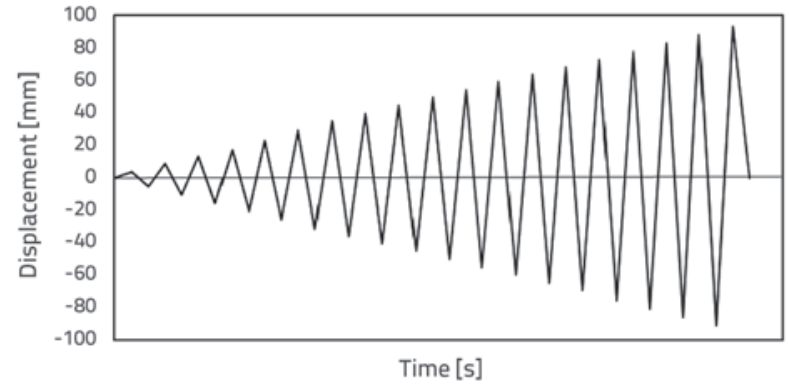

Figure 3. Displacement amplitudes used in laboratory tests and FEA

\subsection{Material properties}

Since this experimental program is conducted to reflect the weak sides of reinforced concrete buildings in Turkey, material properties have been selected with this purpose in mind. The compressive strength of concrete is $20 \mathrm{MPa}$ and the elasticity modulus is 20,000 MPa. On the other hand, the tensile strength of approximately 2 MPa may be accepted for this material. The compressive strength for gas concrete and brick infill wall have been set to 1.0 and 4.1 MPa, respectively. In addition, the moduli of elasticity for gas concrete and hollow brick masonry have been set to $800 \mathrm{MPa}$ and $1000 \mathrm{MPa}$, respectively. The material properties of concrete included compression testing of cubes (measuring $15 \times 15 \times 15 \mathrm{~cm}$ ) for columns and beams, and tensile testing of reinforcement rebars. The material characteristics for mortar, gas concrete, and brick units are taken from the company providing the samples. The results are given in Table 1. The brick unit and gas concrete block dimensions are $13,5 x$ $19 \times 19 \mathrm{~cm}$ and $60 \times 25 \times 19 \mathrm{~cm}$, respectively.

Table 1. Mechanical properties of materials used in tests

\begin{tabular}{|l|c|}
\hline Property & Mean [MPa] \\
\hline Compressive strength of concrete & 20 \\
\hline Elasticity modulus of concrete & 1.0 \\
\hline Compressive strength of gas concrete & 800 \\
\hline Elasticity modulus of gas concrete & 0.15 \\
\hline Shear strength of gas concrete & 4.1 \\
\hline Compressive strength of brick wall & 1000 \\
\hline Elasticity modulus of brick wall & 0.33 \\
\hline Shear strength of brick wall & 2000 \\
\hline
\end{tabular}

Elasticity moduli of materials are determined based on the classic modal analysis (Table 1) using the finite element model updating procedure [33], which consists of manual tuning using special software. The manual tuning comprises manual changes of the model geometry and modelling parameters by trial and error, directed by engineering judgment. The aim of this is to ensure better correspondence between analytical model results and experimental test results. The modal analysis method is used to specify dynamic properties of the system via measurements using a special shaker shown in Figure 4.b. Sensitive accelerometers are used in the study to determine vibrations in the structure arising from the shaker. Since the accelerometers are designed for intervals of specific sensitivity and frequency, the choice of accelerometer to be used in the study was quite important. Properties of the accelerometer used in this study are given in Table 2, and the accelerometer is shown in Figure 5. The accelerometers are attached to the frame by drilling a hole. Quattro four channel data acquisition cell, shown in Figure 4.a, is used in the study. Signals come from accelerometers and shaker vibrations transfer to this cell, and then these signals are recorded and processed by the SignalCalc

Table 2. Technical specifications of KB12VD Piezoelectric accelerometer

\begin{tabular}{|c|c|c|c|}
\hline Sensitivity & $10000 \mathrm{mV} / \mathrm{g} \pm 5 \%$ & Service temperature & $-20-80{ }^{\circ} \mathrm{C}$ \\
\hline Linear frequency interval & $0.08-260 \mathrm{~Hz}$ & Dimensions & $\mathrm{R}=50 \mathrm{~mm}, \mathrm{H}=37 \mathrm{~mm}$ \\
\hline Measuring range & $-0.6-0.6 \mathrm{~g}$ & Total mass & $150 \mathrm{~g}$ \\
\hline
\end{tabular}


240 software. Modal analysis tests of specimens for gas concrete and brick masonry infilled RC frame are shown in Figure 6 and Figure 7, respectively. Investigations are repeated separately for $0-50 \mathrm{~Hz}, 0-100 \mathrm{~Hz}$ and $0-200 \mathrm{~Hz}$ intervals, either under the effects of shaker and/or environment. The aim is to observe the noise effects that can occur using many different types of enforcement. The data acquired from Impuls and Burst Random type enforcement are used. Results are obtained using Butterworth Band-Stop infiltration technique for the $0-50 \mathrm{~Hz}$ interval. The first frequencies of the bare frame, gas concrete wall without plaster and with plaster, are measured as 18.06 $\mathrm{Hz}, 18.21 \mathrm{~Hz}$, and $20.61 \mathrm{~Hz}$, respectively. On the other hand, second frequencies are estimated as $22.31 \mathrm{~Hz}, 22.26 \mathrm{~Hz}$, and 24. $12 \mathrm{~Hz}$, respectively. For brick infilled frame, the first frequencies are $17.38 \mathrm{~Hz}$,
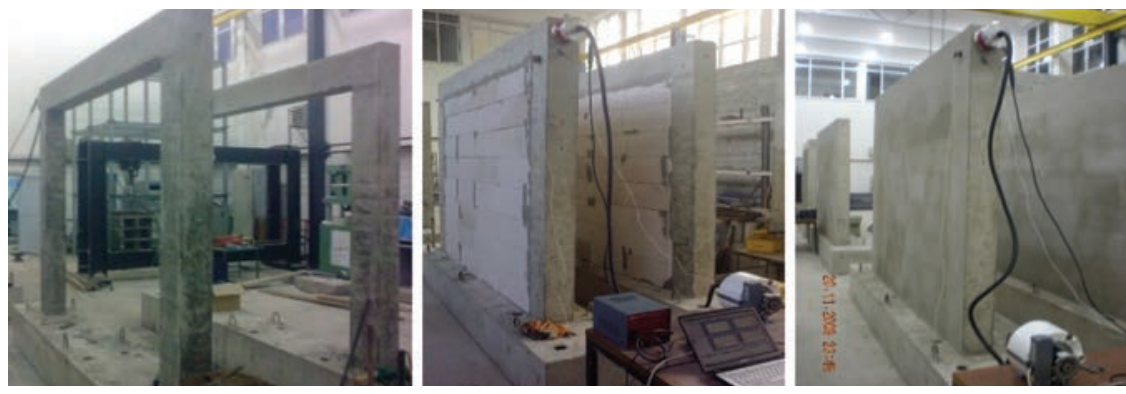

Figure 6. Classic modal analysis tests for gas concrete frame
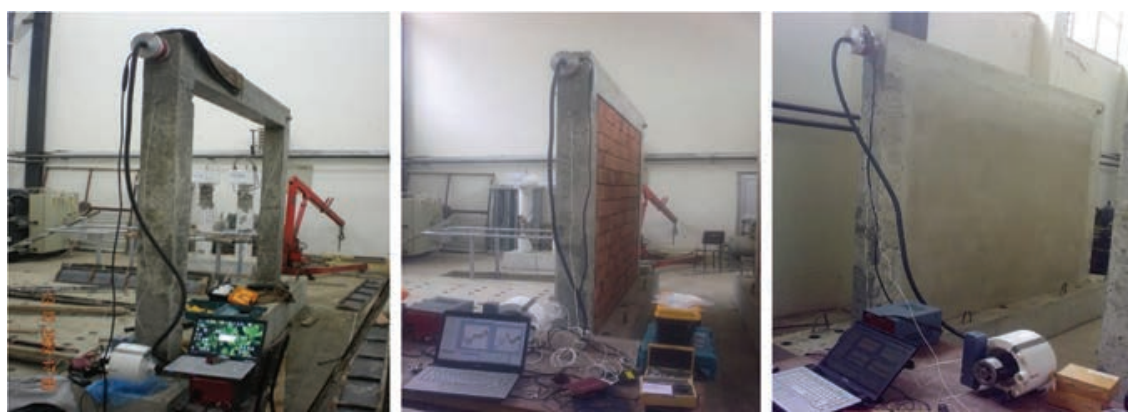

Figure 7. Classic modal analysis tests for brick masonry frame

17.77 Hz, and $18.24 \mathrm{~Hz}$ for bare, brick without and with plaster, respectively. The second frequencies are determined as 21.07 $\mathrm{Hz}, 21.34 \mathrm{~Hz}$ and $27.07 \mathrm{~Hz}$, respectively. The results showed that the plaster has an important effect on the lateral behaviour of the infilled RC frame even at small strain level.

a)


Figure 4. a) Quattro four channel data acquisition cell; b) shaker
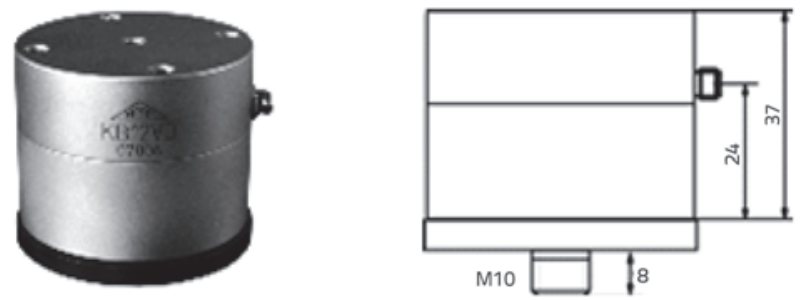

Figure 5. KB12VD Piezoelectric accelerometer

\subsection{Experimental test results}

The experimental test setup and instrumentation are shown in Figure 8. A servo-hydraulic actuator was used to apply reversed cyclic lateral loads to the top of test frames. The loading protocol used in the study is given in Figure 3. Lateral loads and top displacements were measured by means of a $500 \mathrm{kN}$ loadcell and a $200 \mathrm{~mm}$ linear potentiometric displacement transducer (LPDT), respectively. These values were recorded by the data acquisition system and transferred to the computer [32].

Hysteretic lateral force- top displacement curves of bare, gas concrete and brick infilled RC frames are given in Figures $9 \mathrm{a}, \mathrm{b}$ and $\mathrm{c}$, respectively. Maximum load carrying capacities are $48.5 \mathrm{kN}, 135.7 \mathrm{kN}$ and $289.1 \mathrm{kN}$ and the corresponding displacements are $49.8 \mathrm{~mm}, 24.1 \mathrm{~mm}$ and $13.3 \mathrm{~mm}$, respectively. Test specimens after cyclic loading are also shown in Figure 5. Horizontal cracks developed at the top and bottom of the columns due to bending in the bare frame specimen. The shear slip and tension failure developed in gas concrete infill, while plastic hinges developed in the top and bottom of the columns of the same specimen. Furthermore, corner crushing of infill was observed in brick infill.

Force-displacement test results for specimens are given in Figure 9d. It can clearly be seen from the figure that the improvement is remarkable for infilled frames compared to bare frame. The increase in load carrying capacity, when compared to the bare frame, is 2.8 times for the gas concrete infilled RC frame and 6 times for the brick infilled RC frame. The increase in initial stiffness for infilled frames with respect to bare frame is significant, while brick infill augmented the stiffness of bare frame more than gas concrete infill. As a result, the contribution of infill to frame for brick infilled specimen finished toward the end of the experimental test at a corresponding displacement of about $70 \mathrm{~mm}$ as shown in Figure 9d, whereas the contribution of gas concrete infill continued until the end of the test. 


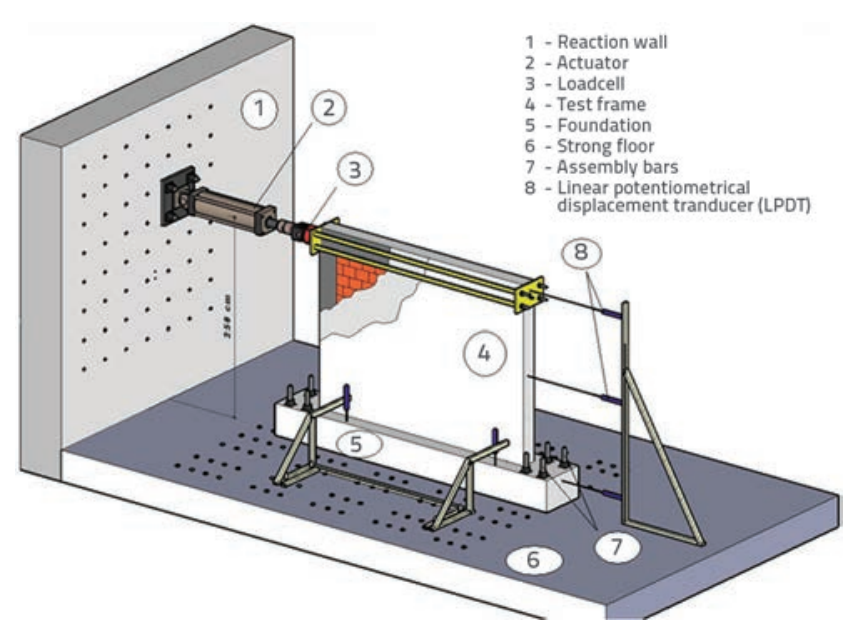

Figure 8. Test setup of experiments [32]
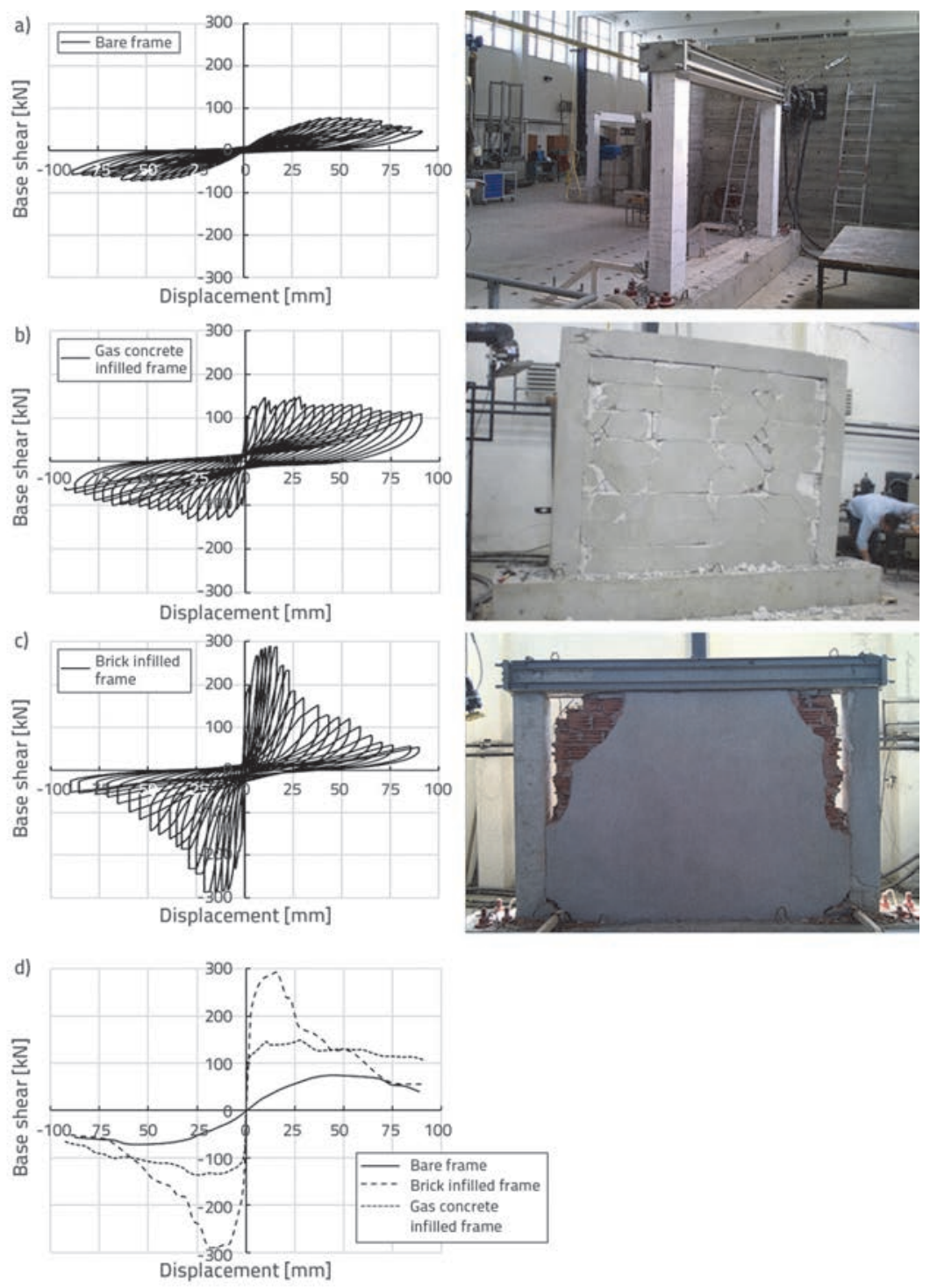

Figure 9. Experimental force-displacement curves of: a) bare frame; b) gas concrete infilled frame; c) brick infilled frame; d) comparison of experimental results

\section{Finite element modelling of infilled RC frame}

\subsection{Finite element modelling of RC frame}

A bare frame, a gas concrete RC frame, and a brick infilled RC frame, are analysed in this study using three different mathematical model approaches for concrete. These approaches are based on the nonlinear finite element method (FEM). A static pushover analysis is carried out using only the positive displacement amplitudes employed in experimental tests (Figure 3). The effects of concrete and steel are not considered separately but rather the reinforced concrete is defined as a homogeneous, isotropic material in the finite element analysis (FEA). In other words, only the behaviour of confined concrete is applied in the FEA. Three different stressstrain characteristics are used to define the effectiveness of material models [35-37]. These material models are explained below in greater detail.

The stress strain relationship suggested in [35] is expressed with appropriate equations, as shown below. The long fraction of the Eqn. (1) stands for the deviation from the linear elastic portion. The stress-strain curve for this model is illustrated in Figure 10

$f=f_{0} \frac{\varepsilon}{\varepsilon_{0}} \frac{n}{n-1+\left(\frac{\varepsilon}{\varepsilon_{0}}\right)^{n}}$

$\varepsilon_{0}=k \cdot 10^{-4} \sqrt[4]{f_{0}}$

$n($ concrete $)=0.4 \cdot 10^{-3} f_{0}+1.0$

$E=\frac{10^{4}}{k} \frac{f_{0}+17.24}{\sqrt[4]{f_{0}}}$

where:

$f_{o}$ - maximum concrete compression strength (MPa)

$\varepsilon_{0}$ - corresponding strain

$n$-approximate function concrete compression strength.

In these equations, $k$ is defined as a function of aggregate type and ranges between $7.63-9.37 \mathrm{~mm}^{1 / 2} / \mathrm{N}^{1 / 4}$

The uniaxial stress-strain relationship of concrete defined in [36] is described in eq (5) and (6): 
$\sigma_{c}=\frac{E_{c} \varepsilon_{c}}{1+\left(R+R_{E}-2\right)\left(\frac{\varepsilon_{c}}{\varepsilon_{0}}\right)-(2 R-1)\left(\frac{\varepsilon_{c}}{\varepsilon_{0}}\right)^{2}+R\left(\frac{\varepsilon_{c}}{\varepsilon_{0}}\right)^{3}}$

$R=\frac{R_{E}\left(R_{\sigma}-1\right)}{\left(R_{\varepsilon}-1\right)^{2}}-\frac{1}{R_{\varepsilon}}$

where $R_{E}=E_{c} / E_{0}$ and $E_{0}=f_{c}^{\prime} / \varepsilon_{0}$. The following values are suggested: $\varepsilon_{0}=0,0025, R_{\varepsilon}=4$ and $R_{\sigma}=4$. The stress-strain curve according to this model is shown in Figure 11

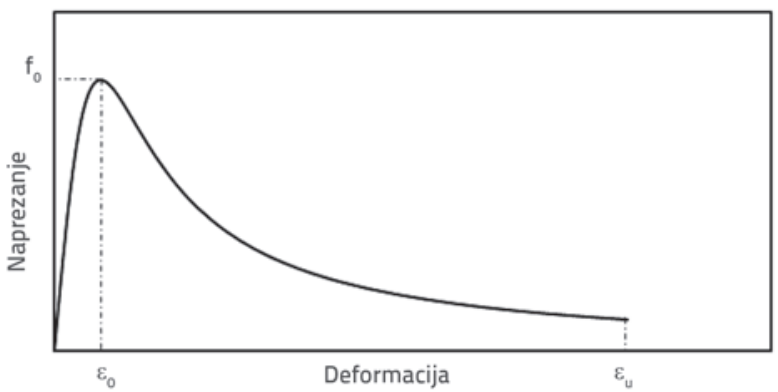

Figure 10. Stress-strain curve for concrete [35]

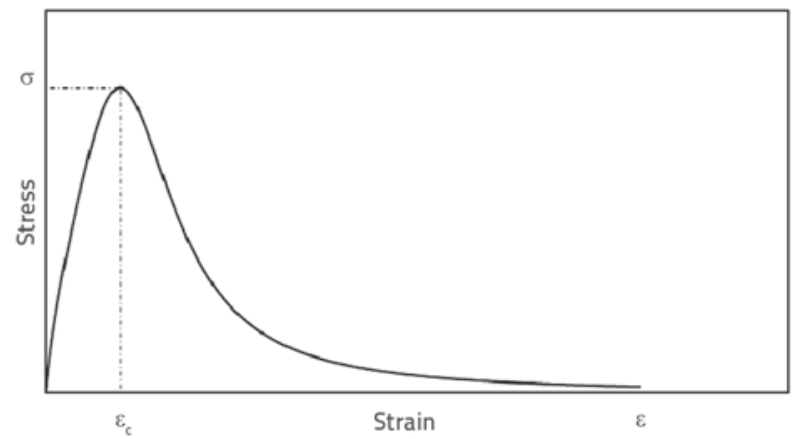

Figure 11. Stress-strain curve for concrete [36]

The Thompson Park material model [37] for confined concrete, widely used in literature, is also used in the nonlinear FEA of infilled RC frames. The Thompson and Park model is intended to define paths of unloading-loading and uses the developed Kent and Park model for stress-strain $(\sigma-\varepsilon)$ curve, as shown in Figure 12. As can be seen in this figure, in cases where $\varepsilon_{c}<\varepsilon_{c o}\left(\varepsilon_{c o}=0.002\right)$, the unloading curve of the load becomes parallel to the origin of the $\sigma-\varepsilon$ curve. When the member is loaded again, the $\sigma-\varepsilon$ curve follows the same path. In cases where $\varepsilon_{c}>\varepsilon_{c 0^{\prime}}$ the unloading curve of load is represented with two straight lines. The slope of the first part of stress during unloading is infinite, while the slope of the second part is defined as $0.5 E_{c} F_{c 1}$. The relations defining stress and strain curve in Thompson and Park model is given below in Figure 8. A detailed mathematical description of this material model can be found in literature [37].

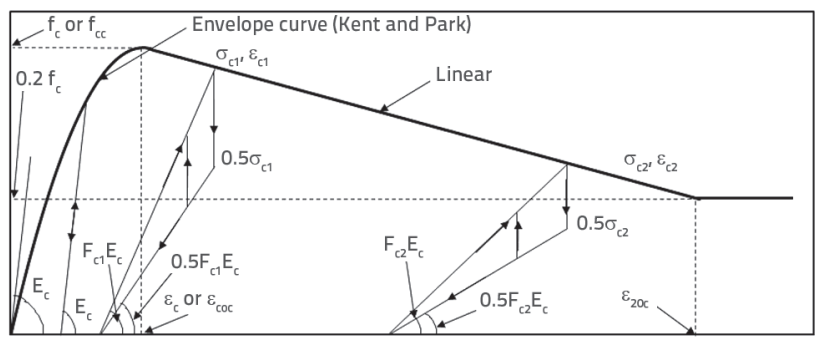

Figure 12. Stress-strain curve for Thompson Park model [37]

\subsection{Finite element modelling of infill wall}

Since masonry walls are affected by various parameters such as unit dimensions, horizontal or vertical width of mortar, material properties of mortar, unit and labour, it is difficult to model these elements. It is a well-known fact that masonry walls can be modelled in three different ways such as macro modelling, simplified micro modelling, and detailed micro modelling.

In macro-modelling, units, mortar and unit-mortar interface are smeared out in a homogeneous continuum. In simplified micro-modelling, expanded units are represented by continuum elements whereas the behaviour of the mortar joints and unit-mortar interface is lumped in discontinuum elements. In detailed micro-modelling, units and mortar in joints are represented by continuum elements whereas the unit-mortar interface is represented by discontinuum elements [38]. A detailed explanation of these models is available in the literature by Lourenço [38].

In the present study, infill walls are adopted as a homogeneous material. In other words, the unit and mortar effects are neglected in the analysis. The Concrete Damage Plasticity (CDP) material model, available in the finite element program ABAQUS [39], is used to represent behaviour of infill walls. A sensitivity study is carried out to adopt the properties of CDP. However, the results of the sensitivity analysis are not given here. A general review of parameters used in this model is given in Section 3.4. For the stress-strain behaviour of the infill wall, the use is made of a material model previously applied to model a masonry bridge presented in [40]. This material model is suggested in [36] for the stress-strain curve of plain concrete. In this model, the uniaxial compression strength is defined as:

$\sigma_{c}=\frac{E_{0} \varepsilon_{c}}{1+\left(\frac{E_{0} \varepsilon_{p}}{\sigma_{p}}-2\right)\left(\frac{\varepsilon_{c}}{\varepsilon_{p}}\right)+\left(\frac{\varepsilon_{c}}{\varepsilon_{p}}\right)^{2}}$

where $\sigma_{c}$ and $\varepsilon_{c}$ are the compressive stress and compressive strain, respectively. $\sigma_{p}$ and $\varepsilon_{p}$ denote the maximum stress and the corresponding strain. $E_{o}$ is the elasticity modulus of the infill wall. Since masonry infill walls exhibit a very brittle behaviour under tension, it is hard to test nonlinear behaviour under 
tension effects. The tension stress of $10 \%$ of the compressive stress has been adopted in this analysis, as this percentage is commonly used in literature.

\subsection{Finite element modelling of wall-frame interaction}

The interaction between the masonry infill wall and the surrounding frame can be modelled in the FEA as spring elements [41] or interface elements [9, 42]. Using an element representing the behaviour between a wall and a frame is important to obtain an accurate result. A surface based cohesive behaviour model is used in the analysis. This model is defined as a surface interaction feature and is used to model the behaviour of traction-separation in the interface. The traction separation criterion used in FEA considers a linear elastic behaviour and this behaviour is expressed as:

$t=\left\{\begin{array}{l}t_{n} \\ t_{s} \\ t_{t}\end{array}\right\}=\left[\begin{array}{lll}K_{n n} & K_{s n} & K_{t n} \\ K_{n s} & K_{s s} & K_{n s} \\ K_{n t} & K_{s t} & K_{t t}\end{array}\right]\left\{\begin{array}{l}\delta_{n} \\ \delta_{s} \\ \delta_{t}\end{array}\right\}=K \delta$

The nominal traction stress vector, $t$, consists of three components (two components in two-dimensional problems): $t_{n^{\prime}} t_{s}$ and (in three-dimensional problems) $t_{t^{\prime}}$ which represent the normal (along the local 3-directions in three dimensions and along the local 2-directions in two dimensions) and the two shear tractions (along the local 1- and 2-directions in three dimensions and along the local 1-direction in two dimensions), respectively. The corresponding separations are denoted by $\delta_{n^{\prime}}$ $\delta_{s}$ and $\delta_{t}[39]$.

\subsection{Calibration of the model}

The systems are modelled and analysed in the ABAQUS finite element program. An 8-node linear brick, reduced integration with hourglass control element (C3D8R) is used to model the RC frame and infill wall. C3D8R elements use reduced integration point which means only one integration point is

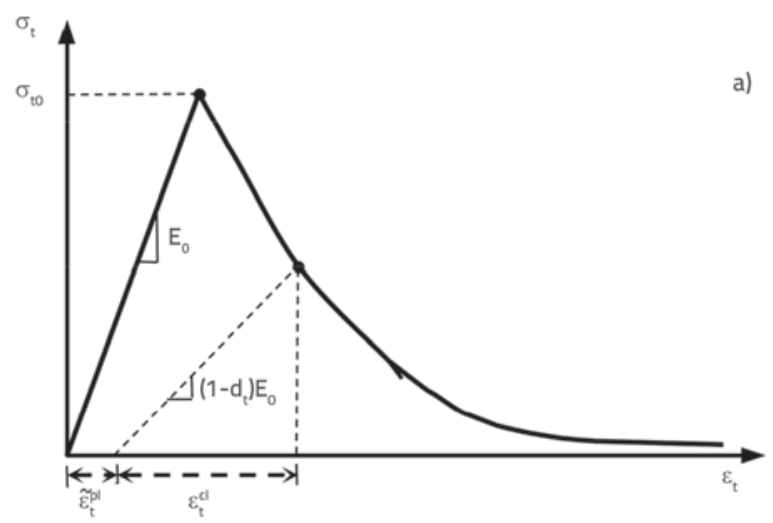

in the centre. The use of an appropriate mesh of hexahedral elements generally provides a solution of equivalent accuracy at less computational time.

The Concrete Damaged Plasticity (CDP) material model available in ABAQUS is used for the infill wall. This model has a general capability for modelling concrete and other quasi-brittle materials in all types of structures. Material parameters used in this model for calibration are given in Table 3. These parameters are: dilation angle $\psi$, eccentricity $\varepsilon$, ratio of initial equibiaxial compressive yield stress to initial uniaxial compressive yield stress $f_{b o} / f_{c 0^{\prime}}$ ratio of the second stress invariant on the tensile meridian to that on the compressive meridian $\mathrm{k}$ and viscosity parameter $x$. The first two parameters are used for shaping the potential flow, while $f_{b o} / f_{c o}$ and $\chi$ are used to define shape of the yield function. The viscosity parameter $(\chi)$ is used to regularize the viscoplastic material. This parameter is used to overcome the convergence problem resulting from softening or rigidity decrease of materials. A small value of the viscosity parameter (small compared to the characteristic time increment) usually helps improve the rate of convergence of the model in the softening regime, without compromising results [39]. The dilation angle $(\psi)$ affects the material behaviour considerably. The analysis performed for infill walls showed that a material exhibits a ductile behaviour in cases when the dilation angle varies from $30^{\circ}$ to $37^{\circ}$, while a brittle behaviour is achieved when this angle is close to $0^{\circ}-1^{\circ}[10]$.

In order to solve the convergence problem, a viscosity parameter of 0.004 is adopted following appropriate parametric studies. A default value of 1 is applied for eccentricity as used for concrete. Default values are once again used for $f_{b o} / f_{c o}$ and $k$. The stress strain relationships used in CDP for tension and compression are illustrated in Figure 13. Damage variables $\left(d_{c}\right.$ and $\left.d_{t}\right)$ are not specified in the analysis. This means that the model behaves as a plasticity model $\left(\varepsilon_{t}^{\sim p l}=\varepsilon_{t}^{\sim c k}\right.$ and $\left.\varepsilon_{c}^{\sim p l}=\varepsilon_{c}^{\sim i n}\right)$, where plastic strain $\left(\varepsilon_{c}^{\sim p l}\right)$ equals cracking strain $\left(\varepsilon_{t}^{\text {Nck }}\right)$ for tension stiffening, while plastic strain $\left(\varepsilon_{c}^{\sim p l}\right)$ equals inelastic strain $\left(\varepsilon_{c}^{-i n}\right)$ for compression hardening.

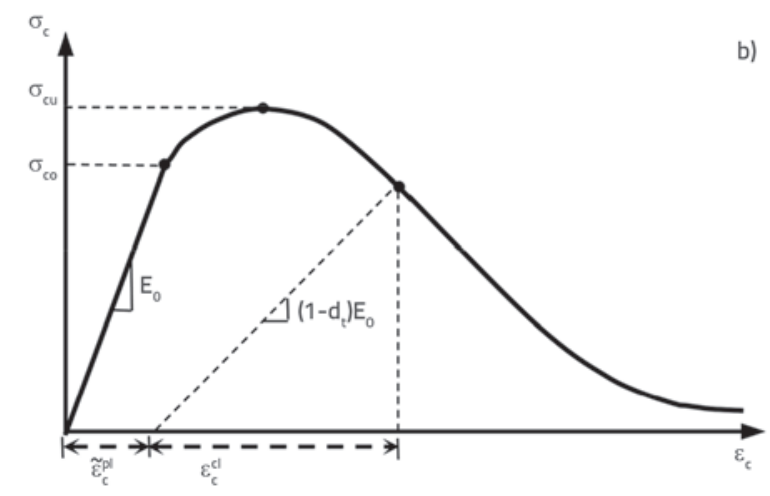

Figure 13. Stress-strain curve in CDP model [39]: a) tension; b) compresion 
Table 3. Material parameters for concrete damaged plasticity

\begin{tabular}{|c|c|c|c|c|}
\hline $\begin{array}{c}\text { Dilation } \\
\text { angle }\end{array}$ & Eccentricity & $\boldsymbol{f}_{b o} / f_{c o}$ & $\mathbf{K}$ & $\begin{array}{c}\text { Viscosity } \\
\text { parameter }\end{array}$ \\
\hline 1.0 & 1.0 & 1.16 & 0.6667 & 0.004 \\
\hline
\end{tabular}

Since this study concentrates on the influence of infill on the RC frame, the concrete and reinforcement are not modelled separately. In the analysis, they are modelled as a homogeneous, single material for simplicity reasons. The interaction between the infill and the surrounding frame is modelled using the surface based cohesive behaviour. This type of interaction is used to model the separation in interface according to tractionseparation criteria. In the traction-separation model, the linear elastic behaviour is approved until the start of damage. The base of the frame is modelled as fixed and there is no gravity load on the frame. The load is applied laterally to the cross-sectional area of the beam.

Since various parameters are effective in modelling, it is rather difficult to calibrate a model in the analysis. However, the experimental test results simplified the calibration process during the FEA.

\section{Results of finite element analysis}

In this study, the full scale, one bay and one storey infilled RC frame systems are modelled and analysed under lateral loads using the nonlinear finite element method (FEM). Two types of infill walls are used, i.e. the gas concrete infill wall and the brick infill wall. The experimental test mechanism with the infilled RC frame modelling is shown in Figure 14. The comparison between experimental and numerical results for bare frame is given in Figure 15.a in terms of a base shear force-top displacement curve. The experimental results are given in both directions. In other words, the direction of negative results is also plotted on the positive side of the figure. A good agreement between experimental and numerical results for Popovics and Thompson-Park model is observed until ultimate lateral load capacity for both positive and negative directions. The initial stiffness is approximately captured in Saenz model. This model suddenly fails at a displacement of $40 \mathrm{~mm}$ and the corresponding drift of almost $2 \%$. The post peak behaviour could not be captured in numerical models while it is satisfactory in Popovics model. The results obtained from the FEA of gas concrete infilled $\mathrm{RC}$ frame system are compared with experimental results in Figure 15b. It can be seen that the experimental and numerical results are compatible. It should be noted that the nonlinear finite element analysis in all three concrete material models can represent the initial rigidity of the system. The load carrying capacity of the infilled frame for experimental test and numerical analysis amounts to approximately $150 \mathrm{kN}$ and $170 \mathrm{kN}$ at a displacement of $28 \mathrm{~mm}$ and $22 \mathrm{~mm}$, respectively. On the other hand, the lateral load bearing capacity from the nonlinear analysis deviates from experimental test results, with a ratio of approximately $8-10 \%$ in all material models. The discrepancies between the models and test data are thought to be due to sudden decrease in the stress-strain curve of material models.

The force-displacement results obtained from the FEA of brick infilled RC frame system are compared with the experimental test shown in Figure 16. It is obvious that experimental and FEA
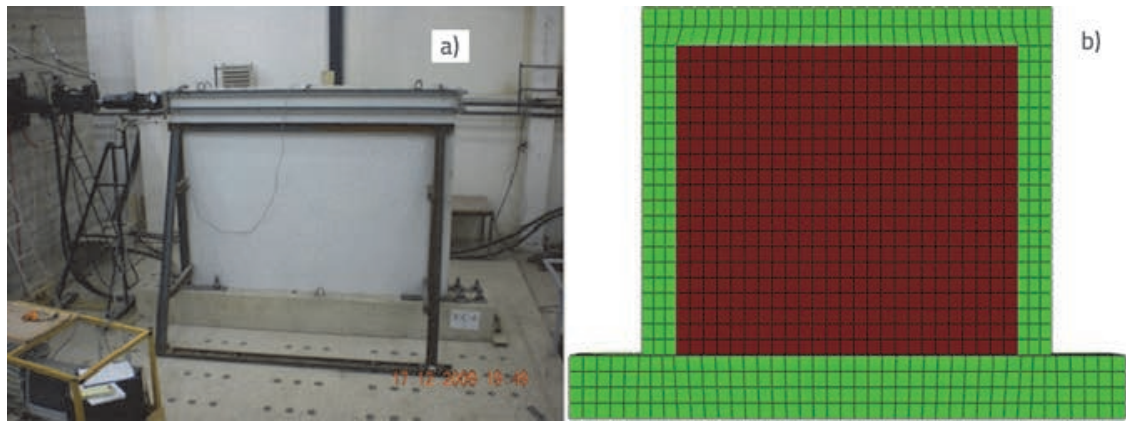

Figure 14. a) Experimental; b) numerical model of infilled RC frame
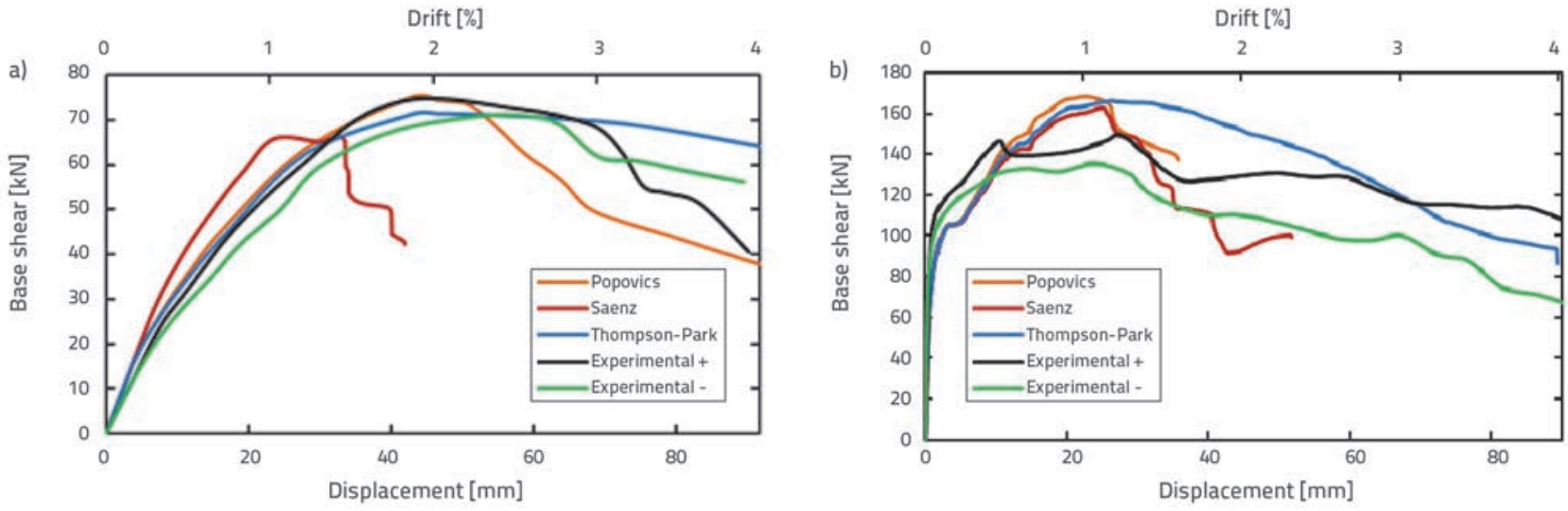

Figure 15. Experimental and numerical view of: a) bare RC frame; b) gas concrete infilled RC frame 


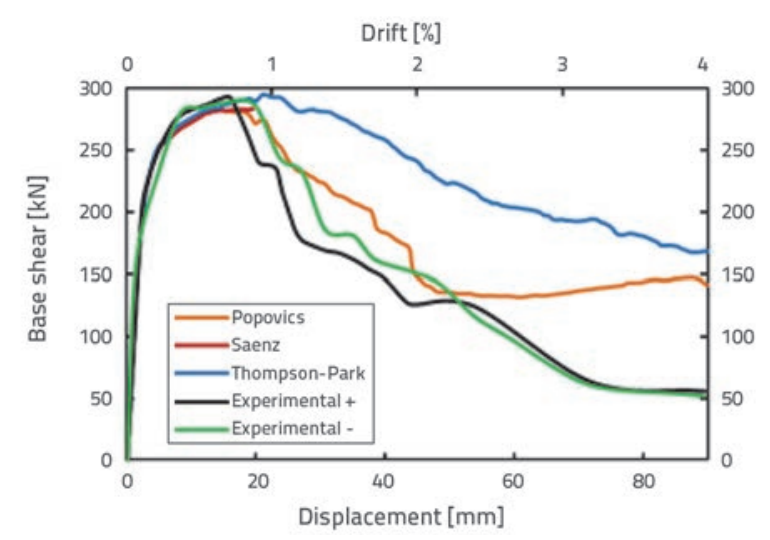

Figure 16. Comparison of experimental and analysis results for brick infilled RC frame
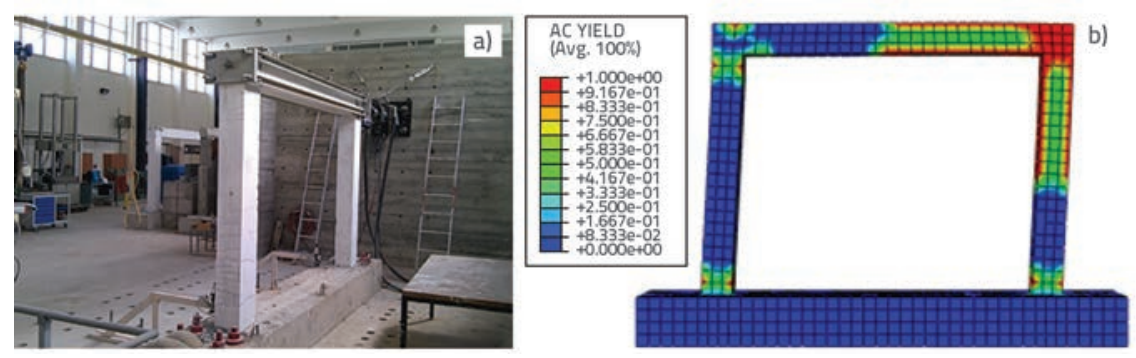

Figure17. a) Experimental; b) numerical failure types for bare RC frame
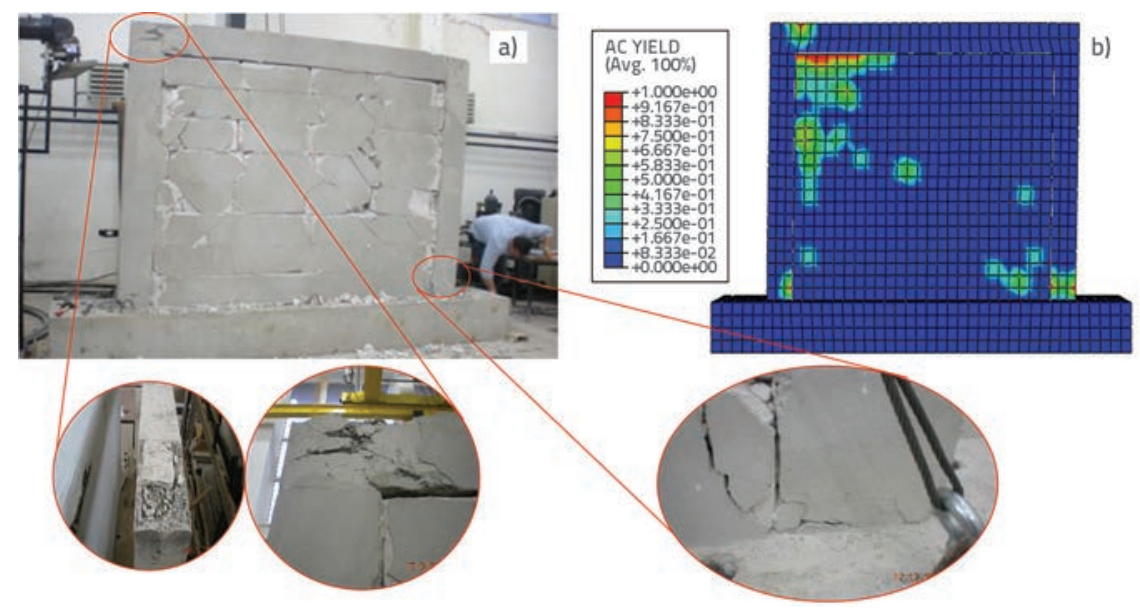

Figure 18. Experimental and numerical failure types for gas concrete infilled RC frame
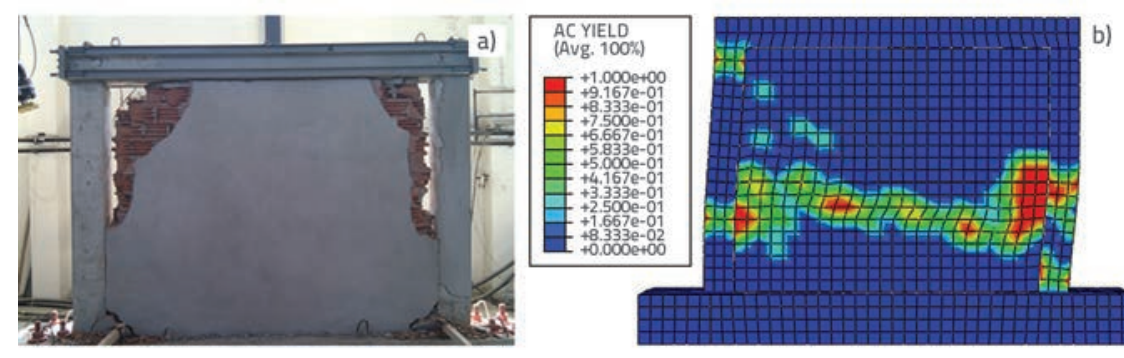

Figure 19. a) Experimental; b) numerical failure types for brick infilled RC frame results are well-suited until reaching the load bearing capacity of the system for three concrete material models. After this point, Saenz model fails because of a sudden decrease in softening regime of the stress-strain curve of the material model. On the other hand, Popovics \& Thompson and Park models differ from each other and experimental results after lateral load bearing capacity, although results of Popovics model are closer to the experimental results.

The details of failure types for the infilled RC frame structures can be found in literature. Only the RC frame failure is addressed in this paper. Failures in frames generally occur as plastic hinges in columns and column-beam joints. Only numerical results of Popovics model are given here since experimental tests are better represented with this model. The failure types observed in the frames from the experimental and finite element analysis results for bare frame are shown in Figure 17. It can clearly be seen that the failure occurred at the top and bottom of column and beam-column joint in both the experimental testing and numerical analysis. The excessive damage at the right beam-column joints developed under an increased lateral displacement. The failure types observed in frames, as based on experimental and FEA results for the gas concrete infilled RC frame, are shown in Figure 18. The figure distinctly shows that plastic hinges that occurred in column-beam joints in experimental testing also formed in the nonlinear FEA. On the other hand, since the infill wall was modelled as a solid element, the failure types developed in units or mortar beds cannot be seen, while the influence of infill on the frame is represented accurately as mentioned earlier in Figures 15 and 16. It can be understood from the analysis that experimental tests can be adequately predicted by the developed numerical model.

The failure types observed according to experimental and FEA results for the brick infilled RC frame are shown in Figure 19. In the experimental test of the brick infilled RC frame, the corner crushing failure was observed at the infill, whereas plastic hinges were revealed at the top and bottom of columns and beam-column joints. The figure shows that plastic hinges occurred near the beam-column joint and at the bottom of columns in experimental testing. On the other hand, in numerical analysis, 
plastic hinges were formed almost at the same locations as in experimental testing, whereas damages occurred near the middle of columns and at the bottom and top during the analysis. However, despite plastic damage around the middle of the columns, the global behaviour was accurately captured, as shown in Figure 19. In this figure, both in test and analysis, the lower region of infill prevents lateral displacement of frame whereas the upper region experiences damages due to excessive displacement.

\section{Conclusion}

The compatibility and efficiency of three different concrete material models (Thompson-Park, Popovics and Saenz), commonly used in literature, are evaluated in this study by simulation of infilled RC frames under lateral load. On the other hand, surface based cohesive behaviour, which is defined as surface interaction feature, is used to model behaviour of the traction-separation in the interface.

The nonlinear FEA results show that equally accurate prediction of results can be made by different mathematical models of reinforced concrete. However, the comparison with experimental results depends on many different parameters relating to strength, reinforcement ratio, etc. Nevertheless, mathematical models used in the analysis provide close results until the load carrying capacity of the system. A detailed analysis may be required for predicting the post-peak behaviour of concrete. In conclusion, the post peak behaviour depends on softening regime of the mathematical model since the postpeak behaviour is substantially related to frame behaviour once the ultimate load is achieved. The Thompson-Park model seems to be the most appropriate concrete model for the bare $\mathrm{RC}$ frame and the gas concrete infilled RC frame. However, more realistic results are obtained by Popovics model for brick infilled fram.

Additionally, the results show that the surface based cohesive behaviour can realistically reflect the interaction between the infill wall and the surrounding frame. Furthermore, the FEA results show that numerical model is capable of estimating the load bearing capacity of the infilled RC frame. It can also capture failure mode in frames such as plastic hinges. However, a detailed micro modelling is required to capture failure modes and crack development in infill walls.

It is recommended by the authors that the concrete material model should be carefully selected, and an in-depth parametric study should be carried out, in order to obtain more accurate FEM results. For further investigations, the analysis should be extended to more experimental studies including some other material models such as the Mander model and other appropriate models.

\section{REFERENCES}

[1] Dogangun, A.: Betonarme Yapıların Hesap ve Tasarımı (11 Edition), Birsen yayınevi, 2014.

[2] Asteris, P.G.: Finite element micro-modelling of infilled frames. Electronic Journal of Structural Engineering, 8 (2008) 8, pp. 1-11.

[3] Bachmann, H.S.: Seismic conceptual design of buildings: basic principles for engineers, architects, building owners, and authorities. SDC. 2003.

[4] Bayülke, N.: Betonarme yapinin dolgu duvari. Türkiye Mühendislik Haberleri, pp. 85-98, 2003.

[5] Mehrabi, A.B., Shing, P.B.: Finite Element Modelling of MasonryInfilled RC frames. Journal of Structural Engineering-ASCE, 123 (1997) 5, pp. 604-613.

[6] Ghosh, A.K., Asce, M., Amde, A.M., Asce, F.: Finite Element Analysis of Infilled Frames, Journal of Structural Engineering, 128 (2002) 7, pp. 881-889, https://doi.org/10.1061/ASCE073394452002128:7881

[7] Al-Chaar, G.K., Mehrabi, T.M.: Finite Element Interface Modelling and Experimental Verificaion of Masonry-Infilled R/C Frames, TMS Journal, 30 (2008) 1.

[8] Kose, M.M.: Parameters affecting the fundamental period of RC buildings with infill walls, Engineering Structures, 31 (2009) 1, pp. 93-102, https://doi.org/10.1016/j.engstruct.2008.07.017

[9] Stavridis, A., Shing, P.B.: Finite-Element Modelling of Nonlinear Behaviour of Masonry-Infilled RC Frames, Journal of Structural Engineering, 136 (2010) 3, pp. 285-296, https://doi.org/10.1061/ (ASCE)ST.1943-541X.116
[10] Resta, M., Fiore, A., Monaco, P.: Non-Linear Finite Element Analysis of Masonry Towers by Adopting the Damage Plasticity Constitutive Model, Advances in Structural Engineering, 16 (2013) 5, pp. 791-803, https://doi.org/10.1260/1369-4332.16.5.791

[11] Kuang, J.S., Yuen, Y.P.: Simulations of masonry-infilled reinforced concrete frame failure, Proceedings of the ICE - Engineering and Computational Mechanics, 166 (2013) 4, pp. 179-193, https://doi. org/10.1680/eacm.13.00002

[12] Asteris, P.G., Cotsovos, D.M., Chrysostomou, C.Z., Mohebkhah, A. Al-Chaar, G.K.: Mathematical micromodelling of infilled frames: State of the art, Engineering Structures, 56 (2013), pp. 19051921, https://doi.org/10.1016/j.engstruct.2013.08.010

[13] Caliò, I., Pantò, B.: A macro-element modelling approach of Infilled Frame Structures, Computers \& Structures, 143 (2014), pp. 91107, https://doi.org/10.1016/j.compstruc.2014.07.008

[14] Cavaleri, L., Di Trapani, F.: Cyclic response of masonry infilled RC frames: Experimental results and simplified modelling, Soil Dynamics and Earthquake Engineering, 65 (2014), pp. 224-242, https://doi.org/10.1016/j.soildyn.2014.06.016

[15] Asteris, P.G., Repapis, C.C., Tsaris, A.K., Di Trapani, F., Cavaleri, L.: Parameters affecting the fundamental period of infilled RC frame structures, Earthquakes and Structures, 9 (2015) 5, pp. 9991028, https://doi.org/10.12989/eas.2015.9.5.999 
[16] Di Trapani, F., Macaluso, G., Cavaleri, L., Papia, M.: Masonry infills and RC frames interaction: literature overview and state of the art of macromodelling approach, European Journal of Environmental and Civil Engineering, 19 (2015) 9, pp. 1059-1095, https://doi.org /10.1080/19648189.2014.996671

[17] Campione, G., Cavaleri, L., Macaluso, G., Amato, G., Di Trapani, F.: Evaluation of infilled frames: an updated in-plane-stiffness macro-model considering the effects of vertical loads, Bulletin of Earthquake Engineering, 13 (2015) 8, pp. 2265-2281, https://doi. org/10.1007/s10518-014-9714-X

[18] Asteris, P.G., Cavaleri, L., Di Trapani, F., Sarhosis, V.: A macromodelling approach for the analysis of infilled frame structures considering the effects of openings and vertical loads, Structure and Infrastructure Engineering, 12 (2016) 5, pp. 551-566, https:// doi.org/10.1080/15732479.2015.1030761

[19] Pantò, B., Caliò, I., Lourenço, P.B.: Seismic safety evaluation of reinforced concrete masonry infilled frames using macro modelling approach, Bulletin of Earthquake Engineering, 2017, https://doi.org/10.1007/s10518-017-0120-z

[20] Faraji Najarkolaie, K., Mohammadi, M., Fanaie, N.: Realistic behaviour of infilled steel frames in seismic events: experimental and analytical study, Bulletin of Earthquake Engineering, 15 (2017) 12, pp. 5365-5392, https://doi.org/10.1007/s10518-0170173-z

[21] Dautaj, A.D., Kadiri, Q., Kabashi, N.: Experimental study on the contribution of masonry infill in the behaviour of RC frame under seismic loading, Engineering Structures, 165 (2018) March, pp. 27-37, https://doi.org/10.1016/j.engstruct.2018.03.013

[22] Nasiri, E., Liu, Y.: Development of a detailed 3D FE model for analysis of the in-plane behaviour of masonry infilled concrete frames, Engineering Structures, 143 (2017), pp. 603-616, https:// doi.org/10.1016/j.engstruct.2017.04.049

[23] Hak, S., Morandi, P., Magenes, G.: Prediction of inter-storey drifts for regular RC structures with masonry infills based on bare frame modelling, Bulletin of Earthquake Engineering, 16 (2018) 1, pp. 397-425, https://doi.org/10.1007/s10518-017-0210-y

[24] Morandi, P., Hak, S., Magenes, G.: Performance-based interpretation of in-plane cyclic tests on RC frames with strong masonry infills, Engineering Structures, 156 (2018), pp. 503-521.

[25] Noh, N.M., Liberatore, L., Mollaioli, F., Tesfamariam, S.: Modelling of masonry infilled RC frames subjected to cyclic loads: State of the art review and modelling with OpenSees, Engineering Structures, 150 (2017), pp. 599-621, https://doi.org/10.1016/j. engstruct.2017.07.002

[26] Zhou, X., Kou, X., Peng, Q., Jintao, C.: Influence of Infill Wall Configuration on Failure Modes of RC Frames, Shock and Vibration, 2018, https://doi.org/10.1155/2018/6582817

[27] Kakaletsis, D.J., Karayannis, C.G.: Experimental investigation of infilled reinforced concrete frames with openings, ACl Structural Journal, 106 (2009) 2, pp. 132-141, https://doi. org/10.14359/56351

[28] Akhoundi, F., Lourenço, P.B., Vasconcelos, G.: Numerically based proposals for the stiffness and strength of masonry infills with openings in reinforced concrete frames, Earthquake Engineering \& Structural Dynamics, 45 (2016) 6, pp. 869-891, https://doi. org/10.1002/eqe. 2688
[29] Sigmund, V., Penava, D. Influence of openings, with and without confinement, on cyclic response of infilled $r-c$ frames - an experimental study, Journal of Earthquake Engineering, 18 (2014) November, pp. 113-146, https://doi.org/10.1080/13632469.201 3.817362

[30] Asteris, P.G., Cavaleri, L., Di Trapani, F., Tsaris, A.K.: Numerical modelling of out-of-plane response of infilled frames: State of the art and future challenges for the equivalent strut macromodels, Engineering Structures, 132 (2017), pp. 110-122, https://doi. org/10.1016/j.engstruct.2016.10.012

[31] Cervenka, V., Jendele, L., Cervenka, J.: ATENA program documentation, Part 1: Theory, Cervenka Consulting, Prague, 2007.

[32] Arslan, M.E.: Experimental and theoretical investigation of behaviour of in-filled RC frames strengthened with GFRP under cyclic loading, Doctoral dissertation, Karadeniz Technical University. 2013.

[33] Bayraktar, A., Altunișik, A.C., Sevim, B., Türker, T.: Seismic response of a historical masonry minaret using a finite element model updated with operational modal testing, JVC/Journal of Vibration and Control, 17 (2011) 1, pp. 129-149, https://doi. org/10.1177/1077546309353288

[34] Timurağaoğlu, M.Ö., Livaoğlu, Ramazan Doğangün, A.: Investigation of the infill wall effect on the dynamic behaviour of RC frames, $6^{\text {th }}$ International Operational Modal Analysis Conference, No:1901649, pp. 505-511, 2015.

[35] Popovics, S.: A numerical approach to the complete stress-strain curve of concrete, Cement and Concrete Research, 3 (1973) 5, pp. 583-599, https://doi.org/10.1016/0008-8846(73)90096-3

[36] Saenz, L.P.: Discussion of Equation for the stress-strain curve of concrete by Desayi P, Krishnan S., ACl Journal, 61 (1964) 9, pp. 1229-1235.

[37] Thompson, K.J., Park, P.: Moment-curvature behaviour of cyclically loaded structural concrete members, Proceedings of Institution of Civil Engineers, 69 (1980), pp. 317-341.

[38] Lourenço, P.B.: Computations on historic masonry structures, Prog. Struct. Engng Mater., 4 (2002) 3, pp. 301-319, https://doi. org/10.1002/pse.120

[39] ABAQUS: ABAQUS Documentation, Dassault Systèmes, Providence, RI, USA. 2013.

[40] Tao, Y., Chen, J.F., Stratford, T., Ooi, J.Y.: Numerical Modelling of a Large Scale Model Masonry Arch Bridge, In Structural Faults and Repair. Edinburgh, United Kingdom, 2012.

[41] Moss, P.J., Carr, A.J. Aspects of the analysis of Frame-Panel Interaction, Bulletin of the New Zealand National Society of Earthquake Engineering, 4 (1971) 1, pp. 126-144.

[42] Mohebkhah, A., Tasnimi, A.A., Moghadam, H.A.: Nonlinear analysis of masonry-infilled steel frames with openings using discrete element method, Journal of Constructional Steel Research, 64 (2008) 12, pp. 1463-1472, https://doi.org/10.1016/j. jcsr.2008.01.016 